\title{
Historical Trajectory of Kí òla mi báa lè dára (That My Future May be Bright): A Yoruba Philosophy of Engagement in Formal Education
}

\author{
Akin-Otiko Akinmayowa \\ Institute of African and Diaspora Studies, University of Lagos, Nigeria
}

Copyright $\bigcirc 2018$ by authors, all rights reserved. Authors agree that this article remains permanently open access under the terms of the Creative Commons Attribution License 4.0 International License

\begin{abstract}
Beliefs and practices are usually guided by philosophies or thought patteras is the case with the Yoruba who believe and regard formal education in high esteem. This high regard and the level of commitment shown to formal education is founded on Kí òla mi báa lè dára (that my future may be bright), a philosophy of educational engagement. This philosophy, over time, has gone through three different phases: the popular phase, the unpopular phase and current phase of review. During the popular phase, the attitude of the Yoruba was mostly towards formal educational engagement. They believed without doubt that formal education was the most effective means to a guaranteed bright future. During the second phase, which is the unpopular phase, the philosophy had lost its appeal because it failed to blend theory with practice. Experience showed that formal education is not the most assured means to a guaranteed future. The current phase, which is the third phase, is a stage of re-examining the philosophy thereby making formal education more appealing to youths. This paper examines Kí òla mi báa lè dára as a basis for explaining the early focus on formal education among the Yoruba, and how this philosophy has determined the attitude of the Yoruba towards formal education. To buttress existing literature, a questionnaire was administered and data collected from 300 randomly selected youths between the age of 12 and 18 . The questionnaires sought to know the role that formal education had played in ensuring a bright future. The paper concluded that formal education is currently no longer perceived as the key factor to achieving a bright future among youths. It also identified ways of improving on $K i$ òla mi báa lè dára as a philosophy of engagement in formal education.
\end{abstract}

Keywords Formal Education, Future of the Youths, Historical Trajectory, Kí òla mi báa lè dára, Yoruba

\section{Introduction}

Yoruba people are known for their commitment to formal education. History also identifies great and popular men and women of Yoruba origin who acquired formal education. This trajectory, in contemporary times, is shifting, as people with little or no formal education are becoming more known, more popular, more celebrated and more respected than their counterparts who have acquired formal education. It is worrisome to imagine that a time would come when a child may not recognize, and may know little or nothing about Wole Soyinka (a Nobel Prize winner and a literary giant), Obafemi Awolowo, etc. but will idolize and know almost everything about a musician or comedian who is not formally educated.

In the past, parents had no difficulty in getting their children to embrace formal education. The bright prospects, and seemingly secured future was clearly visible as was evident in the lives of some living (and dead) elders who succeeded in life because of their educational background. These experiences were backed up by Kí òla mi báa lè dára (that my future may be bright). Kí òla mi báa lè dára is linked to the increasing quest for free education, which began in Yoruba land. When Obafemi Awolowo began the movement for free education in Nigeria, it was clear that the Yoruba had a peculiar interest and love for formal education.

They saw formal education as prestigious and as "one of the most cherished values... which shaped their thinking patterns and behavioral dispositions." [12] Formal education was introduced by the West, and then, every parent proudly ensured that his or her children acquired at least the basic formal education. There are numerous examples of parents who either deprived themselves of the basic comfort of life, or sold their possessions and anything sellable, in order to fund their children's education. Stories are also replete of persons of the older generation who engaged in menial jobs to earn money and pay their school 
fees by themselves. This was possible because they were guided by Kí òla mi báa lè dára, a philosophy of educational engagement.

The post-independence generation of Yoruba people strongly believed that formal education is pivotal to integrated development. They were convinced that an increase in the number of formally educated personnel in the continent is ipso facto an increase in her level of human development. [8] But this belief has in fact gone through changes in history. The Yoruba philosophy or guiding principle for formal education is different today from what it used to be. Formal education used to be seen as the main 'passport' to future success, but the story is different today. Today's reality shows that the centrality of formal education to individual success is fast being perceived as a mere slogan among the teeming Yoruba youths in Nigeria.

The change in the philosophy of engaging in formal education brings out the trajectory in the history of formal education among the Yoruba. This change is of keen interest, more than ever now, when politicians are promising free formal education and the educational policy of Nigeria makes formal education compulsory to a certain level by the adoption of 6-3-3-4 system of education. These educational policies are being enacted even though, many young Nigerians do not find formal education as interesting and promising as it used to be, and where they cannot avoid formal education, they get the basic or the minimum formal education before venturing into other things. This shift in the philosophy of engagement in formal education is so because unlike the past when formal education guaranteed future success, there is no guarantee today that the future of a youth with formal education alone will be bright.

\section{History of Yoruba and their Educational Affiliation}

The Yoruba people are an ethnic group of South-Western and North-Central Nigeria. They are also found in Southern and Central Benin. Their population is believed to be over 40 million in total and the majority of the people that constitute the population are Nigerians. According to the CIA World Facebook, the Yoruba make up $21 \%$ of the country's population. Among the Yoruba, (like in other tribes), there are two types of education: the indigenous and formal types of education. The indigenous type of education is defined as the process of cultural transmission and the process whereby the adult members of the society carefully guide the development of infants and young children, introducing them to the culture of the society. [3] Indigenous education for the Yoruba is beyond being literate. It is a holistic development, and it is èko. Èko as a concept means "the actual display and consistent demonstration of the epistemic features of knowledge, understanding, wisdom and other ethical values of excellence in character, honesty and modesty in attitude, and self-restraint in action and expression." [12]For the Yoruba, emphasis is on raising individuals who are good, disciplined and well behaved. These intrinsic values of indigenous education are of utmost importance to the Yoruba. "Yoruba traditional education revolves around good character (iwa), Yoruba lay more emphasis on Iwa and it is the end product of all training that one gets from both home and society." [8] It can be said that if one has all the formal education possible and has no iwa, the individual is worse than one who is without any formal education. Formal education must promote good character.

The indigenous understanding of education for the Yoruba is not merely a question of being bookish and having prowess in Arithmetic and the Queen's English. [9] To be educated is understood in relation to the concept of omo lu àbí, that is, to be a good person of integrated personality, who demonstrates fairly well the positive use of the mental, physical and psychological features of the human person, as well as moral uprightness in his/her life in society. [4] This is different from formal education, which began in Nigeria with the missionary at Badagry in 1842. The main thrust of formal education is literacy and the empowerment of individuals for formal engagements. The missionaries taught literacy alongside evangelization, especially in Lagos and Abeokuta where the educated returnees from Sierra Leone settled. Every student was prepared for literacy and not to become omo lú àbí. Formal education is different from indigenous education, such that "in spite of the fact that there are no formal structures created within which individual can read and write, traditional African societies believed that education holds the fabrics of the society together and they see it as the culture that is systematically, but consciously passed from one generation to the other in order to improve the level attained by previous generations." [2]

\section{The philosophy of Kí òla mi báa lè dára}

Kí òla mi báa lè dára, a philosophy (way of thinking) is essentially a product of a blend of formal Western education and the Yoruba indigenous form of education. It is personalistic in orientation because it focuses on the development of the individual. There are three-dimensional reflections of what motivated Kí òla mi báa lè dára as a philosophy of education among the Yoruba.

i) Motivational Dimension: The first dimension is that it is a motivational philosophy. It does not promote education for the intrinsic nature of education. The missionaries and Western traders introduced formal education in order to have interpreters and to create a bridge between the Europeans and the indigenous people. The person with both formal and indigenous education (good character) ended up with white collar jobs which are a lot less tedious when compared to jobs like farming, serving at the King's palace, etc. They were also given more opportunities to get integrated into the Western culture. "In the traditional (pre-colonial) African society, education was regarded as a means to an end and not as an end in itself. That is, 
education was mainly functional in objective." [4] Since formal education was portrayed and promoted as a means to an end, people were attracted and motivated to embrace it for its promise. It is certain that if the end/promises of formal education were eliminated, there would have been little or no interest in formal it. It would not have been so widely embraced by the Yoruba.

ii) Evidence Dimension: Young people were motivated to be formally educated because of what they had seen in the lives of those that had been educated before them. $K i$ òla mi báa lè dára would not have motivated in a vacuum, it became effective because it relied on practical examples found in the lives of those that the youths lived with, knew or have heard about. Among the Yoruba, there was Bishop Ajayi Crowther, who was a clergy man and the first to write a book in Yoruba language as well as in Igbo, Isoama-igbo in 1857. [17] Some others are: Obafemi Awolowo, an icon and a foremost politician, and in the contemporary times, there is Professor Wole Soyinka, an author and a Nobel Prize laureate, and so many others. The Yoruba go beyond words, to the recognizable success they see in the lives of their forebears.

iii) Real-time Dimension: Kí òla mi báa lè dára as a philosophy is such that, beyond words, the Yoruba had real time examples to relate with, it was believed that individuals who engaged in a bled of formal education and indigenous education, had their future improved upon. A blend of formal and indigenous education essentially was believed to be a key to making the future better. Formal education gave the blueprint to freedom, Awolowo was often quoted to have said, "to free the people, educate them" this belief led him to develop a template for free universal primary education. Before the introduction of formal education in 1952, only $35 \%$ of children within the school age bracket attended school. The philosophy of Ki ola mi báa lè dára was embraced because formal education promised a bright future for individuals.

\section{Historical trajectory of the philosophy of Kí òla mi báa lè dára.}

The first phase (from the inception of formal education till late 90s): The first phase of Kí òla mi báa lè dára was based on personal interest and personal reward. This is reflected in the pronoun ' $m i$ ' (my). A bled of formal and indigenous education was seen as a means to personal development, growth and success. Formal education was believed to guarantee future success of individuals who acquire it. The focus of formal education was not so much the development of the community but the development of the individual. The missionaries and their associates who received formal education seemingly had more enviable lives compared to their folks who did not have formal education. Those with formal education spoke English and were able to read the Bible and write down other things. They had more chances of becoming teachers and some travelled abroad on scholarship for further studies. Since the missionaries were connected to high authorities, they naturally favoured the formally educated ones. Formal education guaranteed exposure and most times, scholarship to study abroad. In the first phase of Kí òla mi báa lè dára, as a philosophy of engagement in formal education, there was a blend of formal and indigenous education as the only way out and "those who did not attend the formal school system were regarded as illiterate, ignorant, primitive, pagans or heathens." [2] They were usually left out of formal and official functions that are outside the cultural settings. For this reason, many Nigerian graduates were mentally and psychologically prepared for formal education and for 'white collar' jobs. Kí òla mi báa lè dára still held sway till the 90s, particularly with regard to what formal education stands for, even despite the fact that the job opportunities began to dwindle and many Nigerians began to experience lack of employment.

The second phase (from late 90 s till early 2000s): In the second phase of Kí òla mi báa lè dára, the effect of unemployment of formally educated Nigerians began to manifest as the necessary blend of formal and indigenous education was no longer as popular as it was during the first phase. By the 90 s, it had become increasingly hard to find the 'white collar' jobs, many of those that had embarked on formal education had remained jobless, underemployed, or disguisedly unemployed, with a larger proportion of existing industries owned by semi-literate entrepreneurs.[1] The philosophy of Kí òla mi báa lè dára gradually began to experience lack of popularity among the Yorubas because of the reality of alternative sources to material success. The bled of formal and indigenous education gradually lost its position as the most popular means to future success. The rise in the unemployment rate was largely attributed to the increased number of school graduates with no corresponding increase in job opportunities. [7] The situation of things in Nigeria made many youths begin to revolt against their parents who still wanted them to rigorously engage in formal education as the most reliable key to future success. This was coming at a point when the country was experiencing a visible lack of satisfaction among those that had engaged in formal education. The 90s witnessed parents encouraging their children to engage in entrepreneurial skills as backups for formal education.

The labour Force Sample Survey conducted by the National Manpower Board in 1966-67 revealed a $1.7 \%$ aggregate unemployment rate for Nigeria. By 1974, it had risen to 6.4. According to Human Resource Research Unit, 1974, by 1984, the unemployment rate had risen to about $26 \%$. Research has also shown that majority of the unemployed are educated. One then wonders what the value of formal education was if one cannot secure a job with it. "About 90\% of all the unemployed in Lagos by 1972 had either full primary or a maximum of full secondary education... The problem of open youth unemployment is not restricted to graduates of primary and secondary schools alone: it has also extended to graduates of higher institutions. [4] 
As at July 1983, it was reported in Daily Sketch, that 34,000 graduates from the NYSC programme were discharged into the labour market with little hope of finding jobs. This situation has continued to worsen ever since. It got so bad that by the $90 \mathrm{~s}$, trust in the effectiveness of formal education to guarantee individual material future was beginning to dwindle beyond control. This situation has not change in recent times as Nigeria's unemployment rate increased to 23.9 percent in 2011 compared with 21.1 percent in 2010 and 19.7 percent in 2009, as revealed by the National Bureau of Statistics (NBS). This pattern has not changed significantly despite the Democracy that has been in place since 1999. The lack of trust has made formal education very unattractive and young lads are looking for alternatives and creating basis for the shift or lack of popularity of formal education among the Yorubas. These days, a lot of youths (Yoruba and other tribes) are seeking career in singing, comedy and many more at the expense of formal education. This is happening because formal education is no longer perceived as a guarantee for success. "The ugly unemployment statistics of Nigeria has been highlighted by the number of applications from higher degree and first degree holders who sought employment as drivers in Dangote group. The staggering figure stands at 13,000 . Of the 13,000 applications received by the Dangote Group for the Graduate Executive Truck Driver, there were six Ph.D, 704 Masters and over 8,460 Bachelor degree holders." [18]All these are indicators that "the economic down turn has driven the unemployment rate of young Nigerian graduates to its highest level. The National Bureau of Statistics affirmed that unemployment rate in Nigeria has risen from 13.3 percent in the second quarter to 13.9 percent in the third quarter of 2016." [14]

Kí òla mi báa lè dára as a philosophy of engaging in formal education is fast becoming unpopular because "unemployment is not an option that all can afford; when employment is hard to find, members of the primary labour force, in their desperation for food, cloth and house for their families, are forced to take on practically any odd jobs, however irregular and marginally productive it may be." [14] In the case of the teeming young Yoruba youths, employment is not the only desire, big money-making jobs or opportunities are what are in vogue. Kí òla mi báa lè dára as a philosophy of engaging in formal education has further lost its popularity with the failure of the ruling class in Nigeria to provide youths who have completed their studies and the compulsory one year National Service, with jobs. It all seem that formal education has failed to secure or guarantee a blissful material future, many have even raised the standard of qualification from a first degree to a Master's degree, yet they are unable to secure white collar jobs. Many parents sent their children to expensive schools in and out of Nigeria and there are no places to hire them. The lack of assurance after a rigorous period of formal education creates the historical shifts in the applicability of the philosophy of Kí òla mi báa lè dára.
Many have described "formal Western Education that entrenched itself in Nigeria... as elitist and non-functional as majority of its products have no marketable skills that would fit them into the world of employment." [5] Formal education as it is today for many Yoruba does not portend success in future. "One of the challenges which the Nigerian economy has to contend with presently is the enormous number of Nigerians who are qualified educationally, who wish to work but unfortunately are unable to find any meaningful employment, if any at all, for themselves." [5] This is creating a shift in the trajectory of Kí òla mi báa lè dára. Many Yoruba youths are seeking alternatives to formal education whereby they learn "the practical skills needed to function successfully in traditional society." [16] It is becoming more acceptable to say that lack of formal education does not shut one out of the possibility of material success.

In the present period, many youths seek alternatives to formal education, because the "education system failed to provide adequate platform for African development especially in the area of human resources." [2] With the lack of assurance in formal education, many have shifted attention to other lucrative and honourable alternatives (trade, handiwork, etc.) just as there are those that have shifted attention to not so honourable alternatives because of the get-rich-quick syndrome which find expression in "pool betting, cultism, lottery racket, 419, trade in hard drug, internal and international prostitution, internet fraud (yahoo yahoo) and so on which are about the only cannon of moral standard known to Nigerian youths of today." [2] It is important to also add that, with the 'gains' (looting and embezzlement) attached to politics in Nigeria, and the fact that lack of formal education is not a barrier, given the visible presence of not so educated persons who are making lots of money from politics, many Nigerians see politics as an alternative to the rigours of formal education. These realities make formal education become less attractive even with its promise of a bright future.

The third phase (contemporary academic view after 2000): this is the state of reinventing Kí òla mi báa lè dára as a philosophy of engaging in formal education because of the undeniable value of education. The third phase became necessary as depicted by the data collected from the questionnaires distributed. A questionnaire was administered to 300 young persons between the age of 12 and 18 and all questionnaires were returned. $20 \%$ (60) of the returned questionnaire hold that they cannot have a bright future without a blend of formal and indigenous education in Nigeria today, while the remaining $80 \%$ (260) made reference to politicians, rich chiefs, footballers, entertainers/comedians, musicians who never went far in their formal studies but are wealthy and recognized in the society. They as well make huge donations to laudable causes in the society, and for this reason, more youths are of the opinion that formal education is not necessary for a bright future. 
There is a striking departure from the kind of example and role models that the youths had in the first phase of the philosophy, where a blend of formal and indigenous education played a significant role in future success of individuals and the role models they have in later phases. Youths in the third phase prefer footballers to professors and many will like to be successful without blending formal education with indigenous education. The low interest in formal education "has put pressure on formal education generally, and tertiary education in particular, to incorporate entrepreneurial training into regular academic programmes." [11]

This shift is what informs the need for the contemporary academic view of Kí òla mi báa lè dára. The need to renew and implant the value and the indispensability of formal education among the youths in Nigeria cannot be overstated. To achieve this third phase, the Federal Government of Nigeria is trying to show that formal education has an intrinsic value even if it does not translate into a materially successful life in future. Acquisition of formal education adds a whole value to one's worldview, how one does things and eventually how one appreciates life. The ultimate goal of formal education should be seen as "to produce a man or woman of character, with the useful skill appropriate to his or her status in life." [11] This is why Nigeria has adopted the 6-3-3-4 educational system.

The third phase of Ki òla mi báa lè dára should re-emphasize and showcase successful educated persons and their contributions to the society. Formal education should give basic socio-cultural values that are not presently found in the formal school curriculum. Character formation should be the end-product of education as is the case in Yoruba culture, educated persons should be omo lu wa bi. [7] The process of reinventing Kí òla mi báa lè dára should be emphasized in formal education because it is only when citizens acquire holistic education with the emphasis on character development and entrepreneurial skills that their future and that of the society can be guaranteed.

This new emphasis will be very valuable in complementing formal education in the third phase, because formal education places little emphasis on the formation of 'omo lu wa bi'. Formal education is not holistic, because character formation is, for the most part missing; formal education comes with Western influence especially in the area of challenges to good and treasured norms and institutions, such as marriage, role of gender in the family, respect and not slavery, etc. Formal education is now merely seen as the means to social and economic advancement. Today not many schools are concerned with the production of omo $l u w a b \mathrm{i}$ as they rather produce marks, awards, grades and positions. [2]

It is important to make formal education support and boost indigenous education and entrepreneurial skills. A shift from formal education as it is today does not mean a failure of education, but a mismanagement of the value of formal education. Many more youths want to develop entrepreneurial skills. "A recent survey of students of selected tertiary institutions in Nigeria revealed that 65 percent of them on graduation would want to become businessmen and women, if they had capital, while 35 percent preferred paid jobs. However, 70 percent of those who preferred paid jobs still desired to retire to their businesses after some years. This indicated that many young Nigerians have traits of entrepreneurship, or are potential entrepreneurs." [10] The goals of Western education are still very relevant and helpful. Following the "The national educational goals which are derived from the Nigeria philosophy as stated in the National Policy on Education (FRN, 2004) are: The inculcation of national consciousness and national unity; the inculcation of the type of values and attitude for the survival of individual and the Nigerian society. The training of the mind in the understanding of the world around; The acquisition of appropriate skills and the development of mental, physical and social abilities and competencies as equipment for the individual to live in and contribute to the development of the society. "It is unfortunate that many decades after Independence in many African countries, a remarkable percentage of the population in these countries are still illiterate." [2] They are still shut out of the value and benefits of formal education.

\section{Critique of the philosophy of Kí òla mi báa lè dára}

Kí òla mi báa lè dára as a philosophy of engaging in formal education among the Yoruba has, over time, guided most of their disposition towards pursuing formal education. The drop in the effectiveness of the philosophy makes it important to critique the philosophy, find an explanation for the shift, and bring about a development on the philosophy. The feedback received from interviews with persons between ages 12 and 18 years gives some insight into the way to go. First, Ki òla mi báa lè dára as a philosophy of engaging in formal education focuses on the individual disposition, and this must change. The reinvention of Kí òla mi báa lè dára, will require a change of the pronoun ' $m i$ ' (my) in the thought pattern of the Yoruba to ' $w a$ ' (us), such that the focus of formal education will shift to the development of the community through the individual instead of the development of the individual's material success. This change will increase the emphasis on what formal education can do for the society beyond the success of individuals. The community should clearly be the focus of formal education, as stated in the National Policy on Education, [13] where "the Federal Government of Nigeria has adopted education as an instrument par excellence for effecting national development."

The second thing to do in re-inventing Kí òla mi báa lè dára is to focus on the intrinsic value of formal education; the purpose of formal education is perceived as a means to 
material benefit. This is important as "amid this high rate of unemployment, the economic watchers have noticed that there is an increasing trend of disinterest by the emerging younger generation in highly labour-intensive works such as agriculture and factory work in preference for white collar jobs, resulting in many preferring to remain in the labour market rather than take up such jobs." [7] Formal education should be perceived as "the processes by which a child or young adult develops abilities, attitudes and other forms of behaviour, which are of positive value to the society in which he lives." [10] Kí òla mi báa lè dára must focus on the good of the individual as well as the good of the society. Formal education must no longer be seen as a means of providing a materially successful future for the individual, rather than the success of the community. The wrong application of the Kí ola mi báa lè dára has defined the change in trajectory from the first to the second phase, which now necessitates a remodeling of the philosophy from an individualistic focus to the communitarian focus.

Formal education should be seen as a means of contributing to the society, such that if formal education will not bring about material reward, people will still be willing to engage in it because the society will recognize and respect them. Formal education as handed down from generations "is an important instrument of change in modern societies. With education, an individual or group of individuals can rise towards more valued positions and rewards in society." [9] There is no gain saying that formal education is by its very nature a valuable enterprise to embark upon, it is intrinsically good and one can say that formal education is necessary for the development of both the individual and the community. The society has come to accept that formal education is a fundamental human right, even if it does not translate to a materially buoyant future. As they say, if one thinks that formal education is expensive, one should then try ignorance.

The individualistic nature and the lack of emphasis on the intrinsic value of education in the philosophy of Kí òla mi báa lè dára have made it important to state that formal education should focus on the development of both the individual and the society. Today, many youths think of formal education as one of the means to success, and so, if education will not lead to monetary success, it does not have their interest.

The common purpose of education is the transmission of accumulated wisdom, knowledge and skills from one generation to another, and the preparation of the youths for the future membership and participation in the life of the society, in its maintenance, growth and development. The above conception is predicated on the fact that education [be it indigenous or formal] has been very instrumental for the emancipation of individuals and the entire society from the shackles of ignorance, want, squalor and diseases. [7]

\section{Conclusions}

Downward interest in formal education among the Yoruba can be traced to the broken link between formal education and individual entrepreneurial success. "In Nigeria, while there is broad acceptance that entrepreneurship is required for promoting self-employment and enhancing business start-ups, little has been done to incorporate entrepreneurship into formal education despite the introduction of Entrepreneurial Skills Development Programs (ESDP) for Nigeria's tertiary institutions by the Federal Government." [11] There are today a number of successful Yoruba people who had little or no formal education but have material success based on their entrepreneurial skills, which is what many young lads are looking for. There must be a three stage return to the past interest in education. First is to talk about the intrinsic value of education without any link to success, such that people should desire to be educated even if material benefits are not guaranteed. There is the need to deemphasize education as capable of bringing about material success only; there are other values beyond material success that come with being formally educated. Education should be engaged in for its intrinsic value. Second is to showcase successful individuals whose successes are linked to the formal education they received. It is important for students to see and know about such personalities and their contributions to the development of the society, so that such may become role models again. And third, it is invaluable to help students see how education can help develop the society and help them see the need to be involved in the development of the society. This can be done through the changing of the pronoun ' $m i$ ' (my) in the theory, to ' $w a$ ' (us), and focus on community value instead of individual education. Formal education should not be seen as the only means to success in future, despite the fact that it brings about the best in whatever way one chooses, focus should be on the blend of formal education with indigenous or holistic education.

\section{Recommendations}

(1) There is the need to promote the intrinsic value of formal education, in such a way that it is pursued for its very sake.

(2) The contributions of successful individuals who have engaged in formal education should be showcased and the link between their success and formal education stressed to encourage young the ones.

(3) All hands should be on deck to help, support and influence the Government in creating jobs for young Nigerians who have laboured to go through formal education, in order to restore confidence in its value and importance. 
(4) There should be incentives such as scholarships for indigent students who want to study.

\section{REFERENCES}

[1] Adejimola, A. S. \& Olufunmilayo, T. 2009. Spinning-off an entrepreneurship culture among Nigerian University Students: Prospects and challenges African Journal of Business Management 3(3). pp. $80-88$.

[2] Ademakinwa Adebisi, 2015. Yoruba Traditional Education Philosophy in the Evolution of a 'Total Man'. International Journal of Humanities and Cultural Studies. Vol. 2. No. 2. pp. 33- 45 .

[3] Adeyemi, M. B. \& Adeyinka, A. A. 2002. Some key issues in African traditional education. McGill Journal of Education 20 (2) 1-5.

[4] Ajeyalemi D., 1987. Education and Employment: A Crisis Point: An Overview in A.M. Ejiogu \& D. Ajeyalemi, (Eds.) Emergent Issues in Nigerian Education (Vol. I). Lagos: Joja Educational Research and Publishers Limited. pp. 60-75.

[5] Ajayalemi, D. \& Ejiogu, A. M. 1987. Issues, Problems and Prospects in Nigerian Education: An Overview in A.M. Ejiogu \& D. Aajeyalemi, (Eds.) Emergent Issues in Nigerian Education (Vol. I). Lagos: Joja Educational Research and Publishers Limited. pp. 1-10.

[6] Akeju, Kemi F. \& Olanipekun, Dayo B. 2014. Unemployment and Economic Growth in Nigeria Journal of Economics and Sustainable Development Vol.5, No.4, 2014. Pp. 138-144.

[7] Awoniyi, T. A. 1975. "Omoluwabi: The Fundamental Basis of Yoruba Traditional Education”. In Abimbola, Wande ed. Yoruba Oral Tradition. Ibadan: Ibadan University Press.

[8] Ayanleke, R. A. 2013. Yoruba Traditional Education System: A Veritable Tool for Salvaging the Crisis Laden Education System in Nigeria Academic Journal of Interdisciplinary Studies Vol. 2 No 6pp. 141-145.
[9] Balogun O.A. 2008. "The Idea of an 'Educated person' in Contemporary African Thought". Journal of Pan African Studies, Vol. 2 No. 3, 2008, pp. 117-128.

[10] DuBey, D. L. Edem, D. A. \& Thakur, A. S. 1984. An Introduction to the Sociology of Nigerian Education. London: Macmillan Publishers. Educational System, Retrieved from http://www.africa.uga.edu/Yoruba/unit_16/cultureunit.html

[11] Essia, U. 2012. Entrepreneurial Culturing of Formal Education Programmes in Nigeria Journal of Sustainable Society. Vol. 1, No. 2, pp. 52-62.

[12] Fafunwa, A. B. 1982. "African Education in Perspective". In Fafunwa, A.B. and J.U. Aisikueds. Education in Africa: $A$ Comparative Survey. London: George Allen and Unwin Ltd.

[13] Fayemi, A. K. \& Macaulay-Adeyelure, O.C. 2009. A Philosophical Examination of the Traditional Yoruba Notion of Education and its Relevance to the Contemporary African Quest for Development. A Journal of the Philosophical Association of Kenya (PAK) New Series. Vol.1 No.2. pp. 41-59.

[14] Federal Republic of Nigeria, 1981. National Policy of Education. Lagos NERDC Press. pp. 5.

[15] Ibara, E. C. 2017. Managing Cross-Border Tertiary Education in an Era of Economic Recession in Nigeria. Research on Humanities and Social Sciences. Vol.7, No.10. pp. 16-20.

[16] Krits, E. \& Ramos, J. 1976. The Measurement of Urban Under-employment. International Labour Review, 113:1. pp. 115-129.

[17] Sule, S. A. \& Oladipo, B. 2013. Introduction to History and Policy of Education. In Soji Oni (Ed.) Foundation Readings in Education. Ibadan: HIS LINEAGE PUBLISHING HOUSE. pp. 127-145.

[18] Vanguard, 2012. November 5, 2012. Online edition. www.vanguardngr.com

[19] Takeupanarm, 2016. Why is Education so Synonymous to the Yoruba? Posted on October 19, 2016. Retrieved from https://takeupanarm.wordpress.com 